\title{
Immunizations in the elderly: do they live up to their promise?
}

\author{
Dietmar Herndler-Brandstetter, Daniel P. Cioca and Beatrix Grubeck-Loebenstein ${ }^{1}$ \\ Institute for Biomedical Aging Research, Austrian Academy of Sciences, Innsbruck, Austria \\ ${ }^{1}$ Head of the Institute of Vaccination Immunology of the Austrian Green Cross Society for Preventive Medicine, Rennweg 10, \\ Innsbruck, Austria
}

Received October 4, 2005; accepted November 11, 2005

(C) Springer-Verlag 2006

\section{Impfungen bei älteren Menschen - halten sie was sie versprechen?}

Zusammenfassung. Zu Beginn des 21sten Jahrhunderts wird unser Gesundheitssystem nicht nur durch neuartige beziehungsweise wiederkehrende Infektionskrankheiten gefordert, sondern auch durch den demographischen Wandel, welcher derzeit in den Industriestaaten stattfindet. Von besonderer Bedeutung ist, dass Infektionserkrankungen bei älteren Menschen häufiger auftreten, einen schwereren Verlauf nehmen und charakteristische Merkmale hinsichtlich klinischer Präsentation und Behandlung aufweisen. Dies ist auf die Abnahme von Immunfunktionen zurückzuführen, welches kollektiv als Immunseneszenz bezeichnet wird. Die bedeutendsten altersassoziierten Veränderungen betreffen das T-Zell-System. Dies hat dementsprechend Auswirkungen auf die Wirksamkeit von Impfungen im Alter. Nichtsdestoweniger spielen Impfungen eine äußerst wichtige Rolle bei der Reduktion der durch Infektionserkrankungen verursachten Morbidität und Mortalität. Der vorliegende Artikel erläutert nun die Auswirkungen von Infektionserkrankungen auf ältere Menschen und vermittelt einen Überblick über den aktuellen Forschungsstand von Impfungen für ältere Menschen. Weiters soll dargestellt werden, welche altersassoziierten Veränderungen des Immunsystems für die verminderte Wirkung von Impfungen verantwortlich sind.

Schlüsselwörter: Impfung, Altern, Immunsystem.

Summary. In the 21st century, public health is not only challenged by newly emerging and re-emerging infectious diseases but also by demographic developments that are taking place in many countries. Importantly, infec-

Correspondence: Prof. Dr. B. Grubeck-Loebenstein, Institute for Biomedical Aging Research, Austrian Academy of Sciences, Rennweg 10, 6020 Innsbruck, Austria.

Fax: +43-512-5839198

E-mail: beatrix.grubeck-loebenstein@oeaw.ac.at tions in the elderly are more frequent, more severe and have distinct features with respect to clinical presentation and treatment. This is due to a decline in the functions of the immune system referred to as immunosenescence. The most important age-related changes affect the $T$ cell system. Although this derogates the protective effect of some vaccines, vaccinations are still considered the most cost-effective medical procedure for preventing morbidity and mortality caused by infectious diseases. The present article aims at outlining the impact of infectious diseases on the elderly and summarizing the progress made in the field of vaccinations of the elderly and how age-related changes within the immune system contribute to the decreased efficacy of vaccines.

Key words: Vaccination, aging, immune system.

\section{Introduction}

Improved public health measures and standards of living, together with medical advances such as immunizations and antibiotics, contributed substantially to the reduction of mortality and morbidity caused by infectious diseases in the 20th century. In particular, the implementation of large-scale vaccination strategies led to the eradication of smallpox in 1980 [1] and to a drastic reduction of poliomyelitis, tetanus, diphtheria, measles, pertussis and meningitis. At the beginning of the 21 st century, vaccinations are still considered the most cost-effective medical procedure for preventing morbidity and mortality caused by infectious diseases. To date, approximately 26 different infectious diseases can be prevented by vaccinations and 61 vaccines are being developed according to a 2004 survey by the Pharmaceutical Research and Manufacturers of America [2]. The new candidate vaccines are intended to provide protection against diseases caused by rotavirus, herpes zoster and papilloma virus and will be commercially available in one to two years (Table 1). Moreover, improved vaccines against influenza, meningitis, pneumonia and tuberculosis are currently being tested in clinical trials (Table 1). 
Table 1. The developmental status of vaccines against some human pathogens

\begin{tabular}{|c|c|c|c|c|c|}
\hline Disease or pathogen & $\begin{array}{l}\text { Product name } \\
\text { of vaccine }\end{array}$ & Company & $\begin{array}{l}\text { Vaccine } \\
\text { composition }\end{array}$ & Type of vaccine & $\begin{array}{l}\text { Developmental } \\
\text { status }\end{array}$ \\
\hline \multirow[t]{3}{*}{ Cytomegalovirus } & - & APMSD, Chiron & $*$ & subunit & phase II \\
\hline & - & MedImmune & $*$ & $?$ & phase I \\
\hline & - & Vical & $*$ & nucleic acid & phase I \\
\hline Diphtheria, Tetanus, & ? & APMSD & dTaP-IPV-Men & - & phase III \\
\hline Pertussis, Poliomyelitis & $?$ & APMSD & dTaP-IPV-HiB & - & phase III \\
\hline \multirow[t]{2}{*}{ Herpes zoster } & $?$ & Merck & $*$ & live-attenuated & phase III \\
\hline & - & GSK & $*$ & subunit & phase I \\
\hline \multirow[t]{3}{*}{ Human papillomavirus } & Cervarix & GSK & $*$ & virus-like particle L1 & phase III \\
\hline & Gardasil & Merck & $*$ & virus-like particle L1 & phase III \\
\hline & - & $\begin{array}{l}\text { Novavax, National } \\
\text { Cancer Institute }\end{array}$ & $*$ & virus-like particle L1 & phase III \\
\hline \multirow[t]{6}{*}{ Influenza } & Fluvirin & Chiron & $*$ & split-protein & re-application \\
\hline & FluMist/CAIV-T & MedImmune & $*$ & nasal, live-attenuated & phase III \\
\hline & - & MedImmune, Wyeth & $*$ & live-attenuated & phase III \\
\hline & FluINsure & ID Biomedical & $*$ & nasal, subunit & phase III \\
\hline & FluBLOK & Protein Sciences & $*$ & subunit & phase III \\
\hline & - & GSK & $*$ & subunit & phase I, II \\
\hline \multirow[t]{4}{*}{ Pneumonia } & - & Wyeth & $*$ & 9 -valent conjugate & phase III \\
\hline & Streptorix & GSK & $*$ & 11-valent conjugate & phase III \\
\hline & - & GSK & $*$ & subunit & phase I \\
\hline & StreptAvax & ID Biomedical & $*$ & subunit & phase II \\
\hline \multirow[t]{2}{*}{ Rotavirus } & Rotarix & GSK, Avant Ther. & $*$ & oral, live-attenuated & phase III \\
\hline & RotaTeq & Merck & $*$ & live-attenuated & phase III \\
\hline Staphylococcus aureus & StaphVAX & Nabi & $*$ & conjugate & phase III \\
\hline \multirow[t]{3}{*}{ Tuberculosis } & rBCG30 & $\begin{array}{l}\text { Aeras Global TB } \\
\text { Vaccine Foundation }\end{array}$ & $*$ & live-attenuated & phase I \\
\hline & - & GSK & $*$ & $?$ & phase I \\
\hline & - & Corixa & $*$ & $?$ & phase I \\
\hline \multirow{3}{*}{$\begin{array}{l}\text { Varicella, Measles, } \\
\text { Mumps, Rubella }\end{array}$} & Priorix-Tetra & GSK & MMR-V & live-attenuated & phase III \\
\hline & ProQuad & Merck & MMR-V & live-attenuated & phase III \\
\hline & Varivax II & Merck & MMR-V & live-attenuated & available \\
\hline
\end{tabular}

Abbreviations: aP, acellular pertussis; APMSD, Aventis-Pasteur MSD; d, diphtheria; GSK, GlaxoSmithKline; HiB, haemophilus influenzae B; IPV, inactivated polio virus; Men, meningitis; MMR-V, measles-mumps-rubella-varicella; T, tetanus.

*, vaccine that protects only against the pathogen indicated under "Disease or pathogen"

Modern immunology is using vaccines to either selectively suppress or enhance the immune response thus making it also applicable for the treatment of non-infectious diseases such as allergy, autoimmunity, Alzheimer's disease and cancer but also to prevent nicotine drug dependency by anti-nicotine vaccination [3]. Recent progress in the development of vaccines against the human papilloma virus that can cause cervix cancer (Table 1) and vaccination with dendritic cells loaded with tumor antigen [4] exemplify the potential of these novel approaches. Furthermore, research activities of the last decade have shown that the chronic inflammatory background apparent in elderly persons may exacerbate the functional pathology and disease course of age-related disorders, such as arteriosclerosis [5], rheumatoid arthritis [6] and Alzheimer's disease [7, 8]. Thus, future immunotherapeutic approaches may take advantage of the recent research progress in identifying the underlying immunological mechanisms of these diseases.

Nevertheless, infectious diseases represent a major challenge to human progress and survival as they are still responsible for approximately $20 \%$ of all deaths in the world. This is of course not only related to microbial and viral factors but also to social and environmental determinants [9]. However, the resurgence of several infectious diseases was supported by the increased occurrence of multiple drug-resistant microorganisms such as Staphylococcus aureus, Mycobacterium tuberculosis, Escherichia coli and Streptococcus pneumoniae. This situation inflicts an enormous economic burden on health care systems all over the world.

However, public health is not only challenged by newly emerging and re-emerging infectious diseases, but also by the demographic revolution that is proceeding in developed countries leading to a dramatic change of the age structure. Today, people in Austria and every other country of the European Union are living longer than at any other time in recorded history. In Austria, life expectancy at birth has increased from 66.5 (1970) to 75.9 years (2003) for males and from 73.4 (1970) to 81.6 years (2003) for females. At present, $21 \%$ of all Austrian citizens are 60 years or older and this population will repre- 
sent $25 \%$ in 2015 and $36 \%$ in 2050 . With respect to the current demographic development in many countries, infectious diseases in geriatric patients are becoming an increasingly important issue, especially because infections in the elderly are not only more frequent and more severe, but also have distinct features with respect to clinical presentation, microbial epidemiology, treatment and infection control. Urinary tract infections, lower respiratory tract infections, skin and soft tissue infections, infective endocarditis, bacterial meningitis, tuberculosis and herpes zoster appear to have a higher prevalence in elderly persons. In developed countries like the United States, pneumonia, influenza and septicemia are still ranked among the ten major causes of deaths in people aged 65 years and older. The causations for increased susceptibility to infectious diseases include epidemiological elements, immunosenescence and malnutrition, as well as age-associated anatomical alterations.

The present article intends to outline the impact of infectious diseases on the elderly and to summarize the current progress in the field of vaccinations of the elderly, what and how vaccines are being improved and how agerelated changes within the immune system contribute to the decreased efficacy of vaccines.

\section{The relevance of infectious diseases and vaccines in the elderly}

The attention of humankind is regularly directed to the outbreak of deadly infectious diseases such as Ebola, Marburg or SARS and to the worldwide spread of AIDS and hepatitis $C$ that are currently affecting together more than 210 million people [10]. Recently, outbreaks of avian influenza in Russia and Kazakhstan alerted the world, because of the fear that the highly pathogenic H5N1 virus may mutate and facilitate human-to-human transmission. However, public attention to diseases that cause substantial morbidity and mortality among the elderly population is less prominent. The most frequent infectious diseases in the elderly include invasive streptococcus pneumoniae infection, influenza, urinary tract and skin infections [11]. Moreover, old individuals may also fail to respond sufficiently to therapy and frequently suffer from opportunistic infections, recurrent infections with the same pathogen or reactivation of latent diseases, such as those caused by mycobacterium tuberculosis and varicella zoster virus. There are no vaccines available for many infectious pathogens that are frequent in the elderly and existing vaccines are underused and do not assure such an effective protection as in the young. Elderly persons for instance, typically have a decreased immune response to pathogens with which they have previously not been in contact, such as rabies and yellow fever virus, or new influenza virus strains. The following paragraphs will now deal with the most important infectious diseases that threaten the elderly population and will present data on their occurrence, vaccine availability and efficacy, vaccination coverage and current health authority recommendations.

\section{Influenza}

Influenza is one of the most important infectious diseases and was responsible for the death of 20 million people after the First World War. In Austria, it is estimated that between 1.000 and 6.000 people die during an epidemic influenza outbreak. Especially elderly people and persons that are chronically ill or otherwise immunocompromised are at enhanced risk. For instance, during influenza epidemics, Barker and Mullooly reported two deaths per 100.000 among healthy people below 65 years of age compared with 797 per 100.000 in those over 65 with two or more high-risk conditions [12]. In contrast to measles, smallpox and poliomyelitis, influenza is caused by viruses that undergo continuous antigenic variation and possess an animal reservoir. Thus, new epidemics and pandemics are likely to occur in the future, and eradication of the disease will be difficult to achieve. Only recently, specific antiviral therapy has become available by the implementation of two neuraminidase inhibitors (Oseltamivir $^{\circledR}$ and Zanamivir $\left.^{\circledR}\right)$. For instance, Oseltamivir ${ }^{\circledR}$ decreases the duration and severity of disease up to $40 \%$ when given within the first 36 hours after symptoms have occurred [13, 14]. Nevertheless, active immunization remains a vital element in the prophylaxis of influenza disease, although the frequently occurring antigenic drift requires an annual modification of the vaccine components according to the recommendations of the WHO. Thus, vaccination has to be repeated annually to ensure protection against the circulating influenza strains (Fig. 1). However, compared with other European countries, influenza vaccination coverage in Austria ranges in the lowest third, with only $15 \%$ of elderly people being vaccinated. In contrast, vaccination coverage in the United States is about $70 \%$ among people aged 65 and above [15]. Although several vaccines are available, the efficacy of many vaccines in preventing influenza disease in elderly persons is only around $56 \%$ [16]. Especially very old and frail persons show a decreased response to influenza vaccines [17]. The reduced vaccine efficacy is due to low levels of IgA and IgG antibodies, delayed peak an-

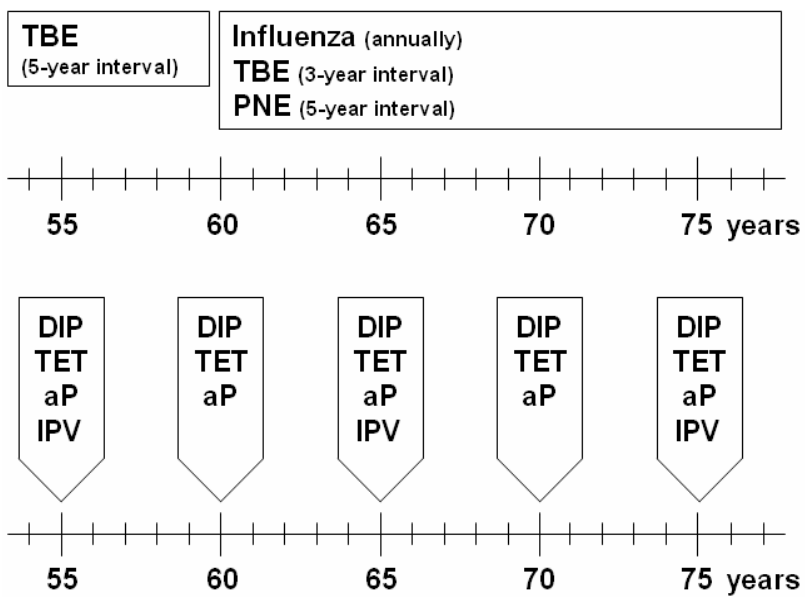

Fig. 1. Vaccination intervals for elderly persons currently recommended by the Austrian health authorities. See text for details. Abbreviations used: DIP, diphtheria vaccine; IPV, inactivated poliomyelitis vaccine; aP, acellular pertussis vaccine; PNE, pneumococcal vaccine; TBE, tick-borne encephalitis vaccine; TET, tetanus vaccine. 
Table 2. Assortment of vaccines that are available in Austria

\begin{tabular}{|c|c|c|c|c|c|}
\hline Disease & $\begin{array}{l}\text { Registered name } \\
\text { of vaccine }\end{array}$ & Company & $\begin{array}{l}\text { Vaccine } \\
\text { composition }\end{array}$ & Type of vaccine & $\begin{array}{l}\text { Merthiolat } \\
\text { added? }\end{array}$ \\
\hline Diphtheria, Tetanus, & $\mathrm{dT}$ reduct & APMSD & dT (Adult) & toxoid & yes \\
\hline \multirow{7}{*}{ Pertussis, Poliomyelitis } & Tdpur & Chiron & $\mathrm{dT}$ & toxoid & no \\
\hline & Polio Salk & APMSD & IPV & inactivated & no \\
\hline & Boostrix & GSK & dTaP (Jun/Adult) & subunit (aP) & no \\
\hline & Repevax & APMSD & dTaP-IPV (Jun/Adult) & inactivated (IPV) & no \\
\hline & Hexavac & APMSD & dTaP-HiB-Polio-HepB (Jun) & - & no \\
\hline & Infanrix-Hib+IPV & GSK & dTaP-HiB-IPV (Jun) & - & no \\
\hline & Infanrix Hexa & GSK & dTaP-HiB-Polio-HepB (Jun) & - & no \\
\hline \multirow[t]{3}{*}{ Hepatitis A } & Epaxal & Berna & * & virosome & no \\
\hline & Havrix & GSK & $*$ & inactivated & no \\
\hline & Twinrix & GSK & HepA+B (Jun/Adult) & inactivated (HepA) & no \\
\hline \multirow[t]{7}{*}{ Influenza } & Begrivac & Chiron & $*$ & split-protein & no \\
\hline & Vaxigrip & APMSD & $*$ & split-protein & no \\
\hline & Addigrip & APMSD & $*$ & subunit & no \\
\hline & Sandovac & Novartis & * & subunit & no \\
\hline & Influvac & Solvay & $*$ & subunit & yes \\
\hline & Fluad & Chiron & $*$ & subunit & no \\
\hline & Inflexal $\mathrm{V}$ & Berna & $*$ & virosome & no \\
\hline Measles, Mumps, Rubella & Priorix & GSK & MMR & live-attenuated & no \\
\hline \multirow[t]{3}{*}{ Pneumonia } & Prevnar & Wyeth & * (Jun) & 7-valent conjugate & no \\
\hline & Pneumo 23 "Merieux" & APMSD & * (Adult) & 23 -valent conjugate & no \\
\hline & Pneumovax 23 & Merck & * & 23 -valent conjugate & no \\
\hline \multirow{2}{*}{ Tick-borne encephalitis } & FSME immune & Baxter & * (Jun/Adult) & inactivated & no \\
\hline & Encepur & Chiron & * (Jun/Adult) & inactivated & no \\
\hline Varicella (Chickenpox) & Varilrix & GSK & * & live-attenuated & no \\
\hline \multirow{2}{*}{ Yellow fever } & Stamaril & APMSD & $*$ & live-attenuated & no \\
\hline & Arilvax & Acambis & * & live-attenuated & no \\
\hline
\end{tabular}

Abbreviations: aP, acellular pertussis; APMSD, Aventis-Pasteur MSD; d, diphtheria; GSK, GlaxoSmithKline; HepA/B, hepatitis $\mathrm{A} / \mathrm{B}$; HiB, haemophilus influenzae b; IPV, inactivated polio virus; MMR, measles-mumps-rubella; T, tetanus

*, vaccine that protects only against the pathogen indicated under "Disease"

tibody titers and shortened maintenance of titers after vaccination. Nevertheless, immunization in elderly people has been shown to be safe, cost-effective and associated with reduced rates of hospitalization and influenzarelated deaths $[18,19]$. In particular, the efficacy of influenza vaccination in reducing mortality in elderly people is greater after repeated annual vaccinations than after first administration [20]. At present, influenza vaccines can be classified in split-protein, subunit, virosomal and live-attenuated vaccines (Table 2). Split-protein vaccines have been used since the 1980ies, are cheap and offer a good protection. Recently, subunit vaccines with new adjuvants have been developed (Fluad ${ }^{\circledR}$, Addigrip ${ }^{\circledR}$ ) that show an increased immunogenicity, a favorable safety profile and may be more suitable for the vaccination of elderly people [21]. Inflexal $\mathrm{V}^{\circledR}$, a virosomal vaccine, displays the highest immunogenicity. Furthermore, new live-attenuated and subunit influenza vaccines are currently in clinical trials and promise to have an increased efficacy of protection (Table 1). Especially live-attenuated influenza vaccines are considered to elicit strong $\mathrm{T}$ cell responses and should therefore increase the antibody levels after vaccination (Fig. 2). Additionally, non-injectible application devices (nasal, oral, transcutaneous) may increase the patient's compliance, especially as the vaccination has to be repeated annually.

\section{Pneumonia}

Infections due to Streptococcus pneumoniae - along with influenza - are the most frequent cause of death in industrialized countries among vaccine-preventable diseases. In Austria, up to 18.000 persons acquire pneumonia each year whereof around $10 \%$ die. An existing primary disease, such as diabetes mellitus or a chronic heart disease may even increase lethality up to $30 \%$. Moreover, 80 to $90 \%$ of deaths associated with Streptococcus pneumoniae infection occur in people aged 60 and older. Thus, antibiotic therapy has to be initiated as soon as possible to reduce the risk of complications due to pneumonia, meningitis or sepsis. Nonetheless, fifty percent of all deaths occur within the first 48 hours despite adequate antibiotic therapy. This is mostly due to the increased occurrence of multiple drug-resistant pneumococcal strains. All-important, people are not necessarily immune after a pneumococcal infection, because there are about 90 different Streptococcus pneumoniae strains and immunity will be guaranteed only to the strain that has caused the infection. In Austria, pneumococcal polysaccharide vaccines are available including 23 strains that cause almost $90 \%$ of the disease (Table 2). These vaccines offer protection against invasive pneumococcal disease in $65 \%$ of the general elderly population [22, 23]. In high risk elderly persons, the protective effect of vaccination seems 


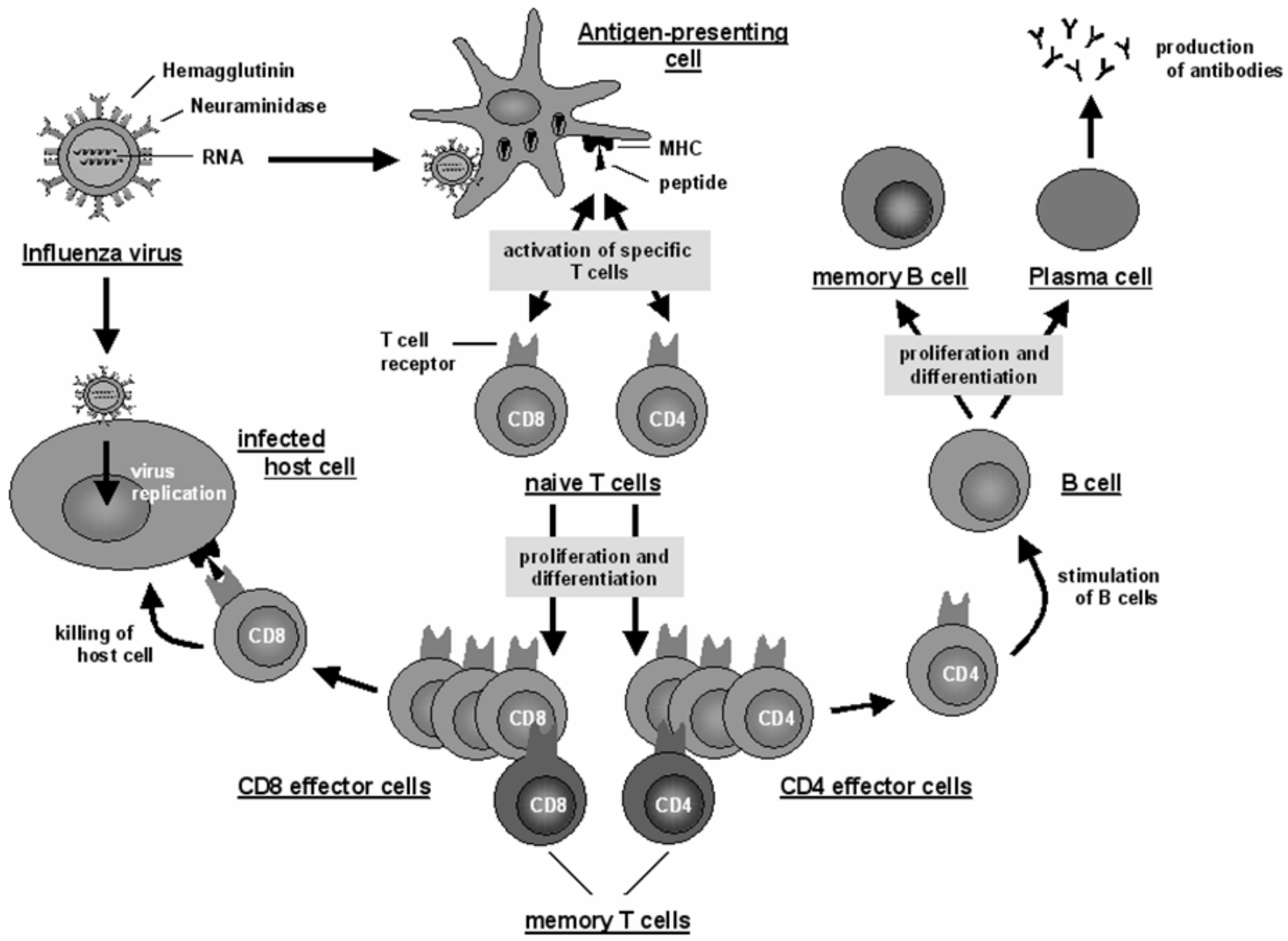

Fig. 2. Schematic representation of the adaptive immune response to a pathogen. The immune system is the body's major defense mechanism against exogenous pathogens and even the slightest alterations of immune function may have deleterious effects on human welfare. Whenever a pathogen invades the human host, the innate (unspecific) and the adaptive (specific) arms of the immune system will be activated. First, the pathogen gets phagocytosed by antigen presenting cells (APC), such as monocytes and dendritic cells. The proteins of the pathogen will be cut into small peptides followed by a vesicular transport of these peptides to the cell surface where they are presented on so-called major histocompatibility complex (MHC) molecules. These peptide-MHC complexes on the cell surface of an APC can now be recognized by a specific T cell receptor (TCR) expressed on $\mathrm{T}$ cells. The process of pathogen recognition leads to activation of the $\mathrm{T}$ cell that will consequently initiate various effector functions. However, one has to distinguish between two types of $\mathrm{T}$ cells that mediate different functions. $\mathrm{CD}^{+}{ }^{+}$(helper) $\mathrm{T}$ cells can stimulate B cells that consequently differentiate into plasma cells and produce antibodies. On the other hand, CD8 ${ }^{+}$(cytotoxic) $\mathrm{T}$ cells mediate killing of tumor cells and host cells that have been infected by a pathogen. The activation of $\mathrm{CD} 4^{+}$and $\mathrm{CD} 8^{+} \mathrm{T}$ cells is also a prerequisite to form long-lasting immunological memory.

to be only moderate. Above all, vaccination coverage among the elderly population is only around 10 to $15 \%$. This may be due to the high costs of the vaccine and its unsatisfying efficacy in elderly people. But more immunogenic vaccines are currently in different phases of clinical trials (Table 1) and promise to be more efficient in old age.

\section{Tuberculosis}

Elderly people also represent the largest target population for tuberculosis (TB) which is still a global health problem as there are 8 million new TB cases and 1.6 million deaths each year. In Austria, the number of TB cases decreased from 1.364 in 1998 to 1.079 in 2002 but it is more prevalent in people aged 55 and over. Moreover, tuberculosis often has an atypical manifestation in old age and is therefore frequently diagnosed with delay. This may lead to increased morbidity and mortality and to a spreading of the disease, in particular within institutionalized elderly persons [24]. Moreover, most infected individuals develop a latent infection that can be reactivated in about $10 \%$ of the patients at any time during their life. Further difficulties include the increased emergence of new, multiple drug-resistant strains with higher transmissibility, the poor efficacy of BCG vaccine in protecting adults and elderly people from pulmonary infection [25] and the increased risk of TB co-infection in HIV positive patients [26]. Yet, the BCG vaccine is not recommended for general use in many countries, such as Austria and the United States, because the vaccine displays adverse side effects and low efficacy in adults, and interferes with skin test screening. However, new TB vac- 
cine candidates have now entered phase I clinical trials (Table 1). They may have a more favorable safety profile and may be able to induce strong cellular immune responses, necessary to protect against an intracellular pathogen such as Mycobacterium tuberculosis.

\section{Herpes zoster}

Herpes zoster is another disease that predominantly occurs in the elderly and is caused by the reactivation of the varicella zoster virus. Primary infection with varicella zoster virus (VZV) has the clinical manifestation of chickenpox and usually occurs in children. The virus then remains latent in human ganglia until its reactivation in the course of an immune suppression or deficiency [27]. The reactivation of VZV results in the clinical manifestation of shingles and post-herpetic neuralgia and is associated with a progressive decline in cell-mediated immunity to VZV, thus rendering older adults more susceptible to VZV. In the near future, routine vaccination of children in Austria will include a new tetravalent vaccine that protects against measles, mumps, rubella and varicella (Table 1). However, these pediatric VZV vaccines are not adequate in boosting $\mathrm{T}$ cell responses in older adults. Fortunately, a vaccine that prevents herpes zoster virus reactivation is currently in phase III clinical trials. This live-attenuated VZV vaccine, which is 14-times more potent than the currently available vaccines that prevent chickenpox, has specifically been developed to protect the reactivation of herpes zoster in elderly people $[28,29]$. This is of particular importance, because older adults were not vaccinated against VZV and may have been infected by VZV. For instance, $95 \%$ of Canadians have had chickenpox by the age of 15 . Thus, reactivation of herpes zoster and its clinical manifestations will remain a serious health threat to the growing elderly population. But new and more potent candidate vaccines may have a beneficial effect by reducing morbidity and mortality due to boosting $\mathrm{T}$ cell responses in older adults.

\section{Cytomegalovirus}

Another herpes virus, the cytomegalovirus (CMV), has also been shown to persist throughout life until its reactivation due to immune suppression or deficiency. Depending on the geographic area, 60 to $100 \%$ of the adult population is infected by CMV [30]. Although immunocompetent persons mostly do not recognize infection as it causes no or few relatively unspecific symptoms, recent research results suggest that CMV favors an accelerated aging of the immune system, because the organism continuously has to warrant immunity to this chronic viral infection [30-32]. This is due to the fact that the virus has evolved numerous mechanisms to continuously escape the host's immune defense [33] and to persist throughout life within the infected organism. This leads to a re-configuration of $\mathrm{T}$ cell immunity due to the accumulation of dysfunctional, virus-specific cells that fail to be eliminated from the system. The accumulation of dysfunctional $\mathrm{CD}^{+} \mathrm{T}$ cells has been associated with a lack of antibody production following influenza vaccination in elderly people [34]. In order to prevent CMV infection, especially to protect HIV-infected patients from CMV co- infection, new candidate vaccines against CMV are now being tested in phase I clinical trials (Table 1). Beyond, these candidate vaccines could also prevent CMV-associated aging of the immune system and its consequences when applied in early life.

\section{Tetanus and diphtheria}

Although tetanus and diphtheria vaccines have been used for routine immunization over decades, few studies exist that document their efficacy in elderly people. There is still evidence that the vaccination coverage among elderly persons is low and even around $40 \%$ of appropriately vaccinated elderly persons do not have protective tetanus-specific antibody concentrations [35-39]. Therefore, Austrian public health authorities have recommended 5- instead of 10-year booster vaccination intervals for people aged $60+$, using a combined vaccine against tetanus, diphtheria and pertussis (Fig. 1). Moreover, strategies have to be developed to draw public attention to the problem of vaccination in the elderly and increase vaccination acceptance.

\section{Pertussis}

Whooping cough (pertussis) is a highly contagious respiratory system infection caused mainly by the bacterium Bordetella pertussis. Pertussis can last for several weeks and affects approximately 700 to 1000 Austrian people annually. Due to the implication of routine childhood vaccination using acellular pertussis vaccines, the high mortality rate among young children has been reduced. Although most infants are being immunized against pertussis, this immunity usually fades during adolescence. Concordantly, a significant increase in reported pertussis incidence among adolescents and adults has been observed [40]. Still, the reported pertussis cases in adults and elderly people are likely to be underestimated because symptoms of disease may be characterless and make clinical diagnosis difficult. There is also evidence that the attack rate of pertussis is high among nonvaccinated elderly people (53\%) [41]. Moreover, $10 \%$ of these elderly people died from intracranial bleeding, while they were symptomatic for pertussis. Thus, regular booster immunizations for adults and elderly persons (Fig. 1) are indispensable to provide sustained levels of antibodies against pertussis.

\section{Tick-borne encephalitis}

Tick-borne encephalitis (TBE) is caused by the TBE virus that is primarily transmitted to humans by infected ticks. TBE is among the most dangerous neuro-infectious diseases in Europe and Asia and is responsible for approximately 10.000 cases of encephalitis annually, most of them occurring in Russia, the Czech Republic and the Baltic states. The percentage of severe disease constitutes 5 to $18 \%$ and approximately $2 \%$ of infected persons have a fatal outcome. Yet, there is no specific therapy available and therefore active immunization provides the only efficient protection against TBE disease. Numerous research results have reported that the commercially available European TBE vaccines (Table 2) are highly immunogenic and well tolerated by both adults and chil- 
dren [42]. Hence, in Austria, disease incidence has been dramatically reduced due to the implementation of an extended TBE vaccination campaign that started in 1981 . By now, Austria is the country with the highest TBE vaccination coverage ( $87 \%$ in 2004) which consequently led to a drop in the number of clinical cases from 438 recorded in 1980 to 54 documented in 2004. Nevertheless, maintenance of the high vaccination coverage is of pivotal relevance, as TBE is a zoonotic arbovirus infection that cannot be eradicated like smallpox. Of particular importance is the fact that $55 \%$ of the annual TBE cases in Austria affect people over 50 years of age and vaccination coverage in this population is only at around $65 \%$. This is so much the worse as elderly people have a higher risk of severe manifestations of TBE. On that account, it will be necessary to increase vaccination coverage among elderly people as well as to assure that they follow the 3-year booster intervals currently recommended (Fig. 1), as they have a more rapid decline in protective antibody levels, too [36]. Regular booster injections in adult life will guarantee the maintenance of a long-lasting humoral immune response [43] and will decrease the risk of immunization failures in elderly people.

\section{Travel vaccines}

Due to increased mobility, elderly persons are also at an enhanced risk of encountering new antigens (e. g. typhoid and yellow fever virus, hepatitis A, rabies virus). For instance, in 1980 only $5 \%$ of Austrians aged over 60 were traveling to a developing country whereas in 1995 this number has reached $15 \%$ and is still increasing. This is a problem, as elderly persons must rely on a limited $\mathrm{T}$ cell repertoire that does not necessarily include full responsiveness to new antigens (see Chapter 2 for details).

Hepatitis A vaccination is currently recommended when traveling to tropical and subtropical countries that carry an enhanced risk of infection. For instance, the risk of hepatitis A infection of travelers to developing countries was estimated to be 3 to 20 cases per 1000 persons per month of stay, varying with destination, living conditions and age [44, 45]. Remarkably, improved sanitary standards in developed countries have reduced the risk of environmental exposure to Hepatitis A virus and have lowered the overall incidence of infection. Paradoxically, susceptibility to the virus has nevertheless increased because of the decrease in natural immunity. Thus, less than $20 \%$ of persons born after 1945 have a natural immunity against Hepatitis A virus [44]. Furthermore, increasing age represents an enhanced risk of severe infection and mortality rates are about two percent for persons older 40 years of age [44]. There is also some evidence of lower antibody titers associated with advancing age. For instance, the seroconversion rates 8 months after two doses of Havrix ${ }^{\circledR}$ were found to be $85 \%$ and $60 \%$ for adults $\leq 35$ years and $>35$ years, respectively [46]. After following a recommended immunization schedule with Twinrix $^{\circledR}$, seroprotection was $92 \%$ and $63 \%$ for adults $<40$ years and $>60$ years, respectively [47]. Considering these results, it may be useful to determine HAV antibodies in elderly persons, as in the case of vaccination failure boosters have shown themselves to be effective [47]. It is further recommended that the vaccine is given at least 3 to 4 weeks before travel due to a slower onset of the antibody response observed in older people [48].

Another important travel vaccine is directed against yellow fever, which is endemic in sub-Saharan Africa and central South America and is caused by a mosquito-borne flavivirus. Neonates and older adults are both at increased risk of severe disease, and mortality rates after infection are highest in these age groups. Yet, there is no specific treatment against yellow fever. Vaccination is the only way to protect persons traveling to regions where yellow fever is endemic. The only vaccine currently available contains a live-attenuated 17D strain virus (Table 2) and has been shown to be safe and highly potent [49]. However, the high sensitivity to temperature makes it necessary that the vaccination is only carried out at specific, WHO-approved institutions. Due to the increased use in international travelers, it has become evident that advanced age may be a risk factor for serious adverse effects [50]. Compared with persons aged 25-44 years, individuals aged $\geq 75$ had an 18-fold greater risk of experiencing serious adverse events after vaccination. The rate of systemic illness requiring hospitalization or leading to death after yellow fever vaccination was reported to be 3.5 per 100.000 among people 65 to 75 years of age and 9.1 per 100.000 for people over 75 years. Moreover, there are no systematic studies available evaluating the efficacy of the vaccine in elderly persons. To strengthen the vaccine's fundamental role in disease prevention and control, efforts to maximize its safety and to ensure its efficacy in elderly persons should be accelerated.

\section{Why do immunity and the protective effect of vaccinations decline in the elderly?}

A wide range of age-related changes in immune system development and function have been identified and are referred to as immunosenescence (Table 3). Immunosenescence is a complex remodeling of the immune system that may contribute significantly to morbidity and mortality in the elderly. It is the consequence of continuous attrition caused by chronic antigenic stress and it has emerged in combination with the extension of lifespan in the $20^{\text {th }}$ century.

Although both cellular and humoral immune responses are modified with advancing age, much of the decrease in immunoresponsiveness seen in elderly people is associated with changes in T cell responses. Hence, the first and most striking age-dependent alteration affecting the immune system is thymic involution, which starts soon after puberty and is complete by the age of 50 $[51,52]$. The thymus, the central lymphoid organ, is responsible for the maturation and eventual selection of fully functioning $\mathrm{T}$ cells, so-called naive $\mathrm{T}$ cells, derived from the bone marrow. Consequently, thymic involution leads to a dramatic decline in the output of naive $\mathrm{T}$ cells and to severely decreased naive $\mathrm{T}$ cell counts. There is also evidence that the remaining naive $\mathrm{T}$ cells in the periphery may get exhausted as they undergo accelerated homeostatic proliferation in order to - in the end unsuccessfully - fill the immunological space and may thus restrict the naive $\mathrm{T}$ cell repertoire and impair the organ- 
Table 3. The most important age-related changes within the specific immune system

\begin{tabular}{lll}
\hline Cell type & Age-related alteration & Reference \\
\hline T cells & $\downarrow$ naive T cell counts due to involution of the thymus & {$[51]$} \\
& $\uparrow$ memory and effector T cell counts & {$[57]$} \\
& $\downarrow$ expression of co-stimulatory molecules (CD28, CD27, CD40L) & {$[59]$} \\
& $\uparrow$ expression of senescence-associated molecules (CD57, KLRG-1) & {$[73]$} \\
& $\downarrow$ proliferative responses and $\downarrow$ T cell signaling & {$[59]$} \\
& $\downarrow$ proliferative capacity due to shorter telomeres and lower telomerase levels & {$[59]$} \\
& $\uparrow$ DNA damage and $\downarrow$ DNA repair & {$[74]$} \\
& $\downarrow$ antigen diversity due to accumulation of effector cells & {$[75]$} \\
& $\downarrow$ functional properties of naive T cells & {$[53,54]$ and } \\
& & unpublished observation \\
& $\downarrow$ apoptosis (programmed cell death) of CD8 T cells & {$[74,76]$} \\
& $\uparrow$ apoptosis of CD4 T cells & {$[74]$} \\
& $\uparrow$ levels of the pro-inflammatory cytokines (e. g. IFN $\gamma$, TNF $\alpha$ and IL-6) & {$[77]$} \\
$B$ cells & $\downarrow$ expression of co-stimulatory molecules (CD27, CD40L) & {$[78,79]$} \\
& $\downarrow$ size and number of germinal centers of the lymph nodes & {$[66]$} \\
& $\downarrow$ antibody affinity (shift from IgG to IgM) & {$[80]$} \\
& $\downarrow$ serum antibodies specific for foreign antigens & {$[81]$} \\
& $\uparrow$ serum antibodies specific for self-antigens & {$[67]$} \\
& $\downarrow$ stimulation by follicular dendritic cells & \\
\hline
\end{tabular}

$K L R G$-1, killer cell-lectin-like receptor G1; $T N F \alpha$, tumor necrosis factor $\alpha$

isms' capability to respond to a broad panel of new pathogens [53-55]. Nevertheless, no age-related changes in the total number of $\mathrm{T}$ cells are observed [56]. This is due to an increase in the number of antigen-experienced $\mathrm{T}$ cells [57]. These antigen-experienced $\mathrm{T}$ cells can be divided into memory and effector $\mathrm{T}$ cells. The latter cell type includes a substantial proportion of senescent cells that accumulate in elderly people and are responsible for maintaining $\mathrm{T}$ cell counts to compensate the loss of naive $\mathrm{T}$ cell regeneration. However, senescent effector $\mathrm{T}$ cells display phenotypic changes (loss of co-stimulatory molecules such as CD28 and CD40L) as well as functional changes (lack of the production of important cytokines, decreased proliferative response, shortened telomeres, increased resistance to programmed cell-death and restricted $\mathrm{T}$ cell diversity) $[58,59]$. Of particular importance, the $\mathrm{CD} 8{ }^{+} \mathrm{CD} 28$ - effector $\mathrm{T}$ cell population displays a distinct cytokine profile, as it produces large amounts of the pro-inflammatory cytokine gamma interferon (IFN $\gamma$ ), but does not produce interleukin 2 (IL-2) and the anti-inflammatory, B cell stimulating cytokine IL-4 [34]. In a recent publication [30], we demonstrated that aging as well as CMV infection lead to a decrease in the size of the naive and early memory $\mathrm{CD}^{+} \mathrm{T}$ cell pool, but to an increase in the number of dysfunctional, IFN $\gamma$-producing $\mathrm{CD}^{+} \mathrm{CD} 28-$ effector $\mathrm{T}$ cells. The accumulation of effector $\mathrm{T}$ cells has been shown to be associated with insufficient efficacy of vaccines to induce antibody production in old age $[34,60]$ and to predict higher mortality [61]. Further, the production of pro-inflammatory cytokines by accumulating effector $\mathrm{T}$ cells leads to ubiquitous chronic inflammatory responses in old age ("inflamm-aging"; [62]), which consequently support the development of age-related chronic diseases, such as arteriosclerosis [5], rheumatoid arthritis [6] and Alzheimer's disease $[7,8]$.
Importantly, elderly people who respond well to influenza vaccination also have high numbers of early memory CD8 ${ }^{+} \mathrm{T}$ cells [63]. Thus, the early memory CD8 ${ }^{+}$ $\mathrm{T}$ cell population, which is a crucial source of IL-2 and IL-4 production and represents a reservoir of great diversity, is an important prerequisite for intact immune responses in elderly persons [64].

As a result, impaired $\mathrm{T}$ cell-mediated immunity as well as defects in antigen presentation by APC, substantially contribute to the decline in B cell specific functions [65]. Although aged individuals have normal numbers of circulating B cells, have no decrease in serum Immunoglobulin (Ig) levels and are capable of mounting robust humoral responses, the antibodies produced are generally of lower affinity and are less protective than those produced by young persons [66]. The process of aging leads to both quantitative and qualitative alterations in the peripheral B cell developmental system and includes the shifts in antibody specificities from foreign to autoantigens and in antibody isotypes from IgG to IgM. Furthermore, it is reported that B cells from aged subjects are stimulated $70 \%$ less efficiently by the follicular dendritic cells than the B cells from young subjects [67], suggesting a correspondingly reduced maintenance of functional memory cells. The result of all these dynamic modifications in the B cell compartment is a reduction of both $\mathrm{T}$ cell-independent and $\mathrm{T}$ cell-dependent $\mathrm{B}$ cell responses [68].

To summarize, the cytokine environment, the $\mathrm{T}$ cell repertoire as well as molecules responsible for cell to cell interactions between $\mathrm{T}$ and $\mathrm{B}$ cells, are major determinants for intact antibody production in old age. Thus, decreased numbers of $\mathrm{CD} 28^{+}$and $\mathrm{CD} 40 \mathrm{~L}^{+} \mathrm{T}$ cells and a lack of cytokines such as IL-2 and IL-4, are both likely to endanger normal $\mathrm{T}$ cell / B cell communication, B cell 
growth, differentiation, and antibody production in the elderly.

\section{How to improve vaccine efficacy?}

There is a tremendous need to increase the protective effect of vaccines in the elderly. Research of the last decade has provided new insights into the molecular mechanisms of the aging immune response, which can be now used for the development of potent vaccines. Actually, there is already a gradual shift from the original focus on humoral immunity to a focus that includes the cellular and innate immune components. In particular, effective vaccines against chronic diseases, such as HIV, hepatitis $\mathrm{C}$, tuberculosis and cancer require strong $\mathrm{T}$ cell responses, to attack virus-infected cells and to protect against disease. Currently, several strategies are being pursued to increase immunogenicity, to minimize adverse side effects and to increase vaccine acceptance by introducing needle-free injection devices. Proven and promising vaccine technologies are used to design conjugate, subunit, live vector, DNA and live-attenuated vaccines [69]. While live-attenuated vaccines stimulate numerous immune components and display enhanced immunogenicity, conjugate and subunit vaccines are often supplemented with adjuvants to ensure their protective effect. Generally, adjuvants can be divided into antigen delivery systems (cationic microparticles, proteasomes and viruslike particles) and immune potentiators (e. g. cytokines). These adjuvants may overcome the proposed age-related functional decline of innate immune responses by targeting pattern-recognition receptors, such as the recently identified toll-like receptors or nucleotide-binding oligomerization domain proteins [70]. The enhanced activation of the innate immune system may also improve antigen processing and presentation leading to more potent $\mathrm{T}$ and $\mathrm{B}$ cell responses. Furthermore, vaccines supplemented with the DNA of a cytokine (e. g. IL-2 or IL-15) may boost immune responses by generating more and long-lived memory $\mathrm{T}$ cells $[71,72]$.

Additional to improving vaccine efficacy, a modification of vaccination strategies for elderly people has been supported by the results of several vaccination trials. A decreased response and a shortened duration of protective immunity following booster immunizations are characteristic features of old age [37]. Therefore, Austrian health authorities have recommended shorter vaccination intervals for tetanus, diphtheria, pertussis and TBE (Fig. 1). Thus, increased public awareness of regular booster vaccinations in adults should be enforced, as these immunization regimes are essential to maintain the ability to respond to recall antigens in old age. Recent results of our laboratory further indicate that long-lasting protection and a good booster effect after a long time can be expected when a live-attenuated vaccine is used for primary immunization (unpublished observation). These findings favor a heterologous prime-boost immunization regime, using potent live-attenuated vaccines at the beginning and continue with inactivated, less immunogenic compounds.

\section{Conclusions}

Consistent with the increased emergence of infectious diseases and the current demographic development in many countries, infectious diseases in geriatric patients are becoming an increasingly important issue. The frequent occurrence and severity of infectious diseases seen in the elderly is mostly related to an age-related decline in the functions of the immune system that also negatively influences the production of protective antibody levels after vaccination. As a result, immunization regimes have been adjusted for elderly individuals and the need to develop more immunogenic vaccines specifically addressing the elderly population has been recognized by manufacturers. Alternative routes of administration should further contribute to an increased vaccine acceptance and a consequent rise in the vaccination coverage among elderly people.

\section{Acknowledgement}

The authors thank DDr. Wolfgang Maurer for comments and critical reading of the manuscript. We would also like to express our thanks to Prof. DDr. E. Huber $\dagger$ who unfortunately died last May. He and the Austrian Green Cross have generously supported our work for many years and are therefore responsible for some of the results our group referred to in this article.

\section{References}

1. Fenner F (1982) A successful eradication campaign. Global eradication of smallpox. Rev Infect Dis 4: 916-930

2. Pharmaceutical Research and Manufacturers of America, 2004 Survey: New Medicines in development for Infectious diseases, http://www.phrma.org/newmedicines/ resources/2004-04-22.130.pdf

3. Cerny T (2005) Anti-nicotine vaccination: where are we? Recent Results Cancer Res 166: 167-175

4. Banchereau J, Palucka AK (2005) Dendritic cells as therapeutic vaccines against cancer. Nat Rev Immunol 5: 296-306

5. Shoenfeld Y, Sherer Y, Harats D (2001) Artherosclerosis as an infectious, inflammatory and autoimmune disease. Trends Immunol 22: 293-295

6. Weyand CM, Fulbright JW, Goronzy JJ (2003) Immunosenescence, autoimmunity, and rheumatoid arthritis. Exp Gerontol 38: 833-841

7. Blasko I, Grubeck-Loebenstein B (2003) Role of the immune system in the pathogenesis, prevention and treatment of Alzheimer's disease. Drugs Aging 20: 101-113

8. Blasko I, Stampfer-Kountchev M, Robatscher P, Veerhuis R, Eikelenboom P, Grubeck-Loebenstein B (2004) How chronic inflammation can affect the brain and support the development of Alzheimer's disease in old age: the role of microglia and astrocytes. Aging Cell 3: 169-176

9. Weiss RA, McMichael AJ (2004) Social and environmental risk factors in the emergence of infectious diseases. Nat Med 10: S70-76

10. 2004. World Health Report

11. Gavazzi G, Krause KH (2002) Ageing and infection. Lancet Infect Dis 2: 659-666

12. Barker WH, Mullooly JP (1982) Pneumonia and influenza deaths during epidemics: implications for prevention. Arch Intern Med 142: 85-89 
13. Treanor JJ, Hayden FG, Vrooman PS, Barbarash R, Bettis R, Riff D, Singh S, Kinnersley N, Ward P, Mills RG (2000) Efficacy and safety of the oral neuraminidase inhibitor oseltamivir in treating acute influenza: a randomized controlled trial. US Oral Neuraminidase Study Group. Jama 283: 1016-1024

14. Welliver R, Monto AS, Carewicz O, Schatteman E, Hassman M, Hedrick J, Jackson HC, Huson L, Ward P, Oxford JS (2001) Effectiveness of oseltamivir in preventing influenza in household contacts: a randomized controlled trial. Jama 285: 748-754

15. (2004) Influenza and pneumococcal vaccination coverage among persons aged $>$ or $=65$ years and persons aged 18-64 years with diabetes or asthma-United States, 2003. MMWR Morb Mortal Wkly Rep 53: 1007-1012

16. Gross PA, Hermogenes AW, Sacks HS, Lau J, Levandowski RA (1995) The efficacy of influenza vaccine in elderly persons. A meta-analysis and review of the literature. Ann Intern Med 123: 518-527

17. Bouree P (2003) Immunity and immunization in elderly. Pathol Biol (Paris) 51: 581-585

18. Nichol KL, Margolis KL, Wuorenma J, Von Sternberg T (1994) The efficacy and cost effectiveness of vaccination against influenza among elderly persons living in the community. N Engl J Med 331: 778-784

19. Mullooly JP, Bennett MD, Hornbrook MC, Barker WH, Williams WW, Patriarca PA, Rhodes PH (1994) Influenza vaccination programs for elderly persons: cost-effectiveness in a health maintenance organization. Ann Intern Med 121: 947-952

20. Ahmed AE, Nicholson KG, Nguyen-Van-Tam JS (1995) Reduction in mortality associated with influenza vaccine during 1989-90 epidemic. Lancet 346: 591-595

21. Iob A, Brianti G, Zamparo E, Gallo T (2005) Evidence of increased clinical protection of an MF59-adjuvant influenza vaccine compared to a non-adjuvant vaccine among elderly residents of long-term care facilities in Italy. Epidemiol Infect 133: 687-693

22. Melegaro A, Edmunds WJ (2004) The 23-valent pneumococcal polysaccharide vaccine. Part I. Efficacy of PPV in the elderly: a comparison of meta-analyses. Eur J Epidemiol 19: 353-363

23. Wagner C, Popp W, Posch M, Vlasich C, RosenbergerSpitzy A (2003) Impact of pneumococcal vaccination on morbidity and mortality of geriatric patients: a case-controlled study. Gerontology 49: 246-250

24. Rajagopalan S, Yoshikawa TT (2000) Tuberculosis in the elderly. Z Gerontol Geriatr 33: 374-380

25. Colditz GA, Brewer TF, Berkey CS, Wilson ME, Burdick E, Fineberg HV, Mosteller F (1994) Efficacy of BCG vaccine in the prevention of tuberculosis. Meta-analysis of the published literature. Jama 271: 698-702

26. McShane H (2005) Co-infection with HIV and TB: double trouble. Int J STD AIDS 16: 95-100; quiz 101

27. Mehta SK, Cohrs RJ, Forghani B, Zerbe G, Gilden DH, Pierson DL (2004) Stress-induced subclinical reactivation of varicella zoster virus in astronauts. J Med Virol 72: 174-179

28. Weir E (2005) Vaccination boosts adult immunity to varicella zoster virus. Cmaj 173: 249

29. Oxman MN, Levin MJ, Johnson GR, Schmader KE, Straus SE, Gelb LD, Arbeit RD, Simberkoff MS, Gershon AA, Davis LE, Weinberg A, Boardman KD, Williams HM, Zhang JH, Peduzzi PN, Beisel CE, Morrison VA, Guatelli JC, Brooks PA, Kauffman CA, Pachucki CT,
Neuzil KM, Betts RF, Wright PF, Griffin MR, Brunell P, Soto NE, Marques AR, Keay SK, Goodman RP, Cotton DJ, Gnann JW, Jr., Loutit J, Holodniy M, Keitel WA, Crawford GE, Yeh SS, Lobo Z, Toney JF, Greenberg RN, Keller PM, Harbecke R, Hayward AR, Irwin MR, Kyriakides TC, Chan CY, Chan IS, Wang WW, Annunziato PW, Silber JL (2005) A vaccine to prevent herpes zoster and postherpetic neuralgia in older adults. $\mathrm{N}$ Engl J Med 352: $2271-2284$

30. Almanzar G, Schwaiger S, Jenewein B, Keller M, Herndler-Brandstetter D, Wurzner R, Schonitzer D, Grubeck-Loebenstein B (2005) Long-term cytomegalovirus infection leads to significant changes in the composition of the CD8+ T-cell repertoire, which may be the basis for an imbalance in the cytokine production profile in elderly persons. J Virol 79: 3675-3683

31. Pawelec G, Akbar A, Caruso C, Solana R, GrubeckLoebenstein B, Wikby A (2005) Human immunosenescence: is it infectious? Immunol Rev 205: 257-268

32. Ouyang Q, Wagner WM, Zheng W, Wikby A, Remarque EJ, Pawelec G (2004) Dysfunctional CMV-specific CD8(+) T cells accumulate in the elderly. Exp Gerontol 39: 607-613

33. Holtappels R, Podlech J, Pahl-Seibert MF, Julch M, Thomas D, Simon CO, Wagner M, Reddehase MJ (2004) Cytomegalovirus misleads its host by priming of CD8 T cells specific for an epitope not presented in infected tissues. J Exp Med 199: 131-136

34. Saurwein-Teissl M, Lung TL, Marx F, Gschosser C, Asch E, Blasko I, Parson W, Bock G, Schonitzer D, Trannoy E, Grubeck-Loebenstein B (2002) Lack of antibody production following immunization in old age: association with CD8(+)CD28(-) T cell clonal expansions and an imbalance in the production of Th1 and Th2 cytokines. J Immunol 168: 5893-5899

35. Steger MM, Maczek C, Berger P, Grubeck-Loebenstein B (1996) Vaccination against tetanus in the elderly: do recommended vaccination strategies give sufficient protection. Lancet 348: 762

36. Hainz U, Aigner K, Asch E, Berger P, Bohmer F, Feldkircher B, Horwath B, Jenewein B, Kassal H, Kistner O, Mack H, Pfeiffer KP, Pils K, Plank J, Renner D, Saurwein-Teissl M, Schwanzer E, Trieb K, Grubeck-Loebenstein B (2002) Vaccine protection in the elderly: are Austrian seniors adequately protected by vaccinations? Wien Klin Wochenschr 114: 187-193

37. Hainz U, Jenewein B, Asch E, Pfeiffer KP, Berger P, Grubeck-Loebenstein B (2005) Insufficient protection for healthy elderly adults by tetanus and TBE vaccines. Vaccine 23: 3232-3235

38. Grubeck-Loebenstein B, Berger P, Saurwein-Teissl M, Zisterer K, Wick G (1998) No immunity for the elderly. Nat Med 4: 870

39. Gergen PJ, McQuillan GM, Kiely M, Ezzati-Rice TM, Sutter RW, Virella G (1995) A population-based serologic survey of immunity to tetanus in the United States. N Engl J Med 332: 761-766

40. Cherry JD (2005) The epidemiology of pertussis: a comparison of the epidemiology of the disease pertussis with the epidemiology of Bordetella pertussis infection. Pediatrics 115: 1422-1427

41. Mertens PL, Stals FS, Schellekens JF, Houben AW, Huisman J (1999) An epidemic of pertussis among elderly people in a religious institution in The Netherlands. Eur J Clin Microbiol Infect Dis 18: 242-247 
42. Kunz C (2003) TBE vaccination and the Austrian experience. Vaccine 21 Suppl 1: S50-55

43. Rendi-Wagner P, Kundi M, Zent O, Banzhoff A, Jaehnig P, Stemberger R, Dvorak G, Grumbeck E, Laaber B, Kollaritsch H (2004) Immunogenicity and safety of a booster vaccination against tick-borne encephalitis more than 3 years following the last immunisation. Vaccine 23: 427-434

44. Steffen R, Kane MA, Shapiro CN, Billo N, Schoellhorn KJ, van Damme P (1994) Epidemiology and prevention of hepatitis A in travelers. Jama 272: 885-889

45. Steffen R (1993) Hepatitis A and hepatitis B: risks compared with other vaccine preventable diseases and immunization recommendations. Vaccine 11: 518-520

46. Hopperus Buma AP, van Doornum GJ, Veltink RL, van Ameijden EJ, Leentvaar-Kuijpers A, Coutinho RA (1997) Immunogenicity of an inactivated hepatitis A vaccine in Dutch United Nations troops. Vaccine 15: 1413-1417

47. Wolters B, Junge U, Dziuba S, Roggendorf M (2003) Immunogenicity of combined hepatitis $A$ and $B$ vaccine in elderly persons. Vaccine 21: 3623-3628

48. Reuman PD, Kubilis P, Hurni W, Brown L, Nalin D (1997) The effect of age and weight on the response to formalin inactivated, alum-adjuvanted hepatitis A vaccine in healthy adults. Vaccine 15: 1157-1161

49. Poland JD, Calisher CH, Monath TP, Downs WG, Murphy K (1981) Persistence of neutralizing antibody 30-35 years after immunization with 17D yellow fever vaccine. Bull World Health Organ 59: 895-900

50. Martin M, Weld LH, Tsai TF, Mootrey GT, Chen RT, Niu M, Cetron MS (2001) Advanced age a risk factor for illness temporally associated with yellow fever vaccination. Emerg Infect Dis 7: 945-951

51. Aspinall R, Andrew D (2000) Thymic involution in aging. J Clin Immunol 20: 250-256

52. George AJ, Ritter MA (1996) Thymic involution with ageing: obsolescence or good housekeeping? Immunol Today 17: 267-272

53. Swain S, Clise-Dwyer K, Haynes L (2005) Homeostasis and the age-associated defect of CD4 T cells. Semin Immunol 17: 370-377

54. Kohler S, Wagner U, Pierer M, Kimmig S, Oppmann B, Mowes B, Julke K, Romagnani C, Thiel A (2005) Postthymic in vivo proliferation of naive CD4+ T cells constrains the TCR repertoire in healthy human adults. Eur $\mathrm{J}$ Immunol 35: 1987-1994

55. LeMaoult J, Messaoudi I, Manavalan JS, Potvin H, Nikolich-Zugich D, Dyall R, Szabo P, Weksler ME, Nikolich-Zugich J (2000) Age-related dysregulation in CD8 T cell homeostasis: kinetics of a diversity loss. J Immunol 165: 2367-2373

56. Stulnig TM, Klocker H, Harwood HJ, Jr., Jurgens G, Schonitzer D, Jarosch E, Huber LA, Amberger A, Wick G (1995) In vivo LDL receptor and HMG-CoA reductase regulation in human lymphocytes and its alterations during aging. Arterioscler Thromb Vasc Biol 15: 872-878

57. Zanni F, Vescovini R, Biasini C, Fagnoni F, Zanlari L, Telera A, Di Pede P, Passeri G, Pedrazzoni M, Passeri M, Franceschi C, Sansoni P (2003) Marked increase with age of type 1 cytokines within memory and effector/cytotoxic CD8+ T cells in humans: a contribution to understand the relationship between inflammation and immunosenescence. Exp Gerontol 38: 981-987

58. Grubeck-Loebenstein B, Wick G (2002) The aging of the immune system. Adv Immunol 80: 243-284
59. Effros RB, Cai Z, Linton PJ (2003) CD8 T cells and aging. Crit Rev Immunol 23: 45-64

60. Goronzy JJ, Fulbright JW, Crowson CS, Poland GA, O'Fallon WM, Weyand CM (2001) Value of immunological markers in predicting responsiveness to influenza vaccination in elderly individuals. J Virol 75: 12182 12187

61. Wikby A, Johansson B, Olsson J, Lofgren S, Nilsson BO, Ferguson F (2002) Expansions of peripheral blood CD8 T-lymphocyte subpopulations and an association with cytomegalovirus seropositivity in the elderly: the Swedish NONA immune study. Exp Gerontol 37: 445-453

62. Franceschi C, Bonafe M, Valensin S, Olivieri F, De Luca M, Ottaviani E, De Benedictis G (2000) Inflamm-aging. An evolutionary perspective on immunosenescence. Ann N Y Acad Sci 908: 244-254

63. Schwaiger S, Wolf AM, Robatscher P, Jenewein B, Grubeck-Loebenstein B (2003) IL-4-producing CD8+ T cells with a CD62L++(bright) phenotype accumulate in a subgroup of older adults and are associated with the maintenance of intact humoral immunity in old age. J Immunol 170: 613-619

64. Herndler-Brandstetter D, Schwaiger S, Veel E, Fehrer C, Cioca DP, Almanzar G, Keller M, Pfister G, Parson W, Wurzner R, Schonitzer D, Henson SM, Aspinall R, Lepperdinger G, Grubeck-Loebenstein B (2005) CD25Expressing CD8+ T Cells Are Potent Memory Cells in Old Age. J Immunol 175: 1566-1574

65. McGlauchlen KS, Vogel LA (2003) Ineffective humoral immunity in the elderly. Microbes Infect 5: 1279-1284

66. Johnson SA, Cambier JC (2004) Ageing, autoimmunity and arthritis: senescence of the B cell compartment implications for humoral immunity. Arthritis Res Ther 6: 131-139

67. Aydar Y, Balogh P, Tew JG, Szakal AK (2002) Age-related depression of FDC accessory functions and CD21 ligand-mediated repair of co-stimulation. Eur J Immunol 32: 2817-2826

68. Eaton SM, Burns EM, Kusser K, Randall TD, Haynes L (2004) Age-related defects in CD4 T cell cognate helper function lead to reductions in humoral responses. J Exp Med 200: 1613-1622

69. Levine MM, Sztein MB (2004) Vaccine development strategies for improving immunization: the role of modern immunology. Nat Immunol 5: 460-464

70. Pashine A, Valiante NM, Ulmer JB (2005) Targeting the innate immune response with improved vaccine adjuvants. Nat Med 11: S63-68

71. Barouch DH, Santra S, Steenbeke TD, Zheng XX, Perry HC, Davies ME, Freed DC, Craiu A, Strom TB, Shiver JW, Letvin NL (1998) Augmentation and suppression of immune responses to an HIV-1 DNA vaccine by plasmid cytokine/Ig administration. J Immunol 161: 1875-1882

72. Kutzler MA, Robinson TM, Chattergoon MA, Choo DK, Choo AY, Choe PY, Ramanathan MP, Parkinson R, Kudchodkar S, Tamura Y, Sidhu M, Roopchand V, Kim JJ, Pavlakis GN, Felber BK, Waldmann TA, Boyer JD, Weiner DB (2005) Coimmunization with an optimized IL-15 plasmid results in enhanced function and longevity of CD8 $\mathrm{T}$ cells that are partially independent of CD4 T cell help. J Immunol 175: 112-123

73. Brenchley JM, Karandikar NJ, Betts MR, Ambrozak DR, Hill BJ, Crotty LE, Casazza JP, Kuruppu J, Migueles SA, Connors M, Roederer M, Douek DC, Koup RA (2003) Expression of CD57 defines replicative senescence and 
antigen-induced apoptotic death of CD8+ T cells. Blood 101: 2711-2720

74. Pawelec G, Barnett Y, Forsey R, Frasca D, Globerson A, McLeod J, Caruso C, Franceschi C, Fulop T, Gupta S, Mariani E, Mocchegiani E, Solana R (2002) T cells and aging, January 2002 update. Front Biosci 7: d1056-1183

75. Naylor K, Li G, Vallejo AN, Lee WW, Koetz K, Bryl E, Witkowski J, Fulbright J, Weyand CM, Goronzy JJ (2005) The influence of age on $\mathrm{T}$ cell generation and TCR diversity. J Immunol 174: 7446-7452

76. Spaulding C, Guo W, Effros RB (1999) Resistance to apoptosis in human CD8+ $\mathrm{T}$ cells that reach replicative senescence after multiple rounds of antigen-specific proliferation. Exp Gerontol 34: 633-644

77. Colonna-Romano G, Bulati M, Aquino A, Scialabba G,
Candore G, Lio D, Motta M, Malaguarnera M, Caruso C (2003) B cells in the aged: CD27, CD5, and CD40 expression. Mech Ageing Dev 124: 389-393

78. Lazuardi L, Jenewein B, Wolf AM, Pfister G, Tzankov A, Grubeck-Loebenstein B (2005) Age-related loss of naive $\mathrm{T}$ cells and dysregulation of T-cell/B-cell interactions in human lymph nodes. Immunology 114: 37-43

79. Mattila PS, Tarkkanen J (1997) Age-associated changes in the cellular composition of the human adenoid. Scand $\mathbf{J}$ Immunol 45: 423-427

80. Weksler ME, Szabo P (2000) The effect of age on the Bcell repertoire. J Clin Immunol 20: 240-249

81. LeMaoult J, Szabo P, Weksler ME (1997) Effect of age on humoral immunity, selection of the B-cell repertoire and B-cell development. Immunol Rev 160: 115-126 